\title{
WSPÓŁCZESNE OBLICZA FEMINIZACJI MIGRACJI I JEJ SKUTKI
}

Migracje nie są zjawiskiem nowym. Od dawna ludzie, a zwłaszcza Polacy migrowali za przysłowiowym „chlebem i wolnością” - o czym przekonuje nas dodatek „Polityki” pod znamiennym tytułem 200 lat nieprzerwanej migracji z ziem polskich ${ }^{1}$. Jednak migracja dwa wieki temu a obecnie ma zupełnie inne znamiona. Tym, co ją najbardziej różnicuje, to kategorie ludzi migrujących ze względu na płeć. Niegdyś migrowali wyłącznie mężczyźni, zaś współcześnie dominującą grupę stanowią kobiety. Z uwagi na ich niespotykaną dotąd liczbę wprowadzono termin „feminizacja migracji”’2. To ona symbolizuje migracje końca XX i początku XXI wieku.

Niniejszy artykuł zwraca uwagę na feminizacje migracji ze wszystkimi jej aspektami. Kobiety migrujące nie tylko biorą na siebie odpowiedzialność za utrzymanie rodziny, ale co gorsza - jako córki, żony i matki - pozostawiają deficyt usług opiekuńczych we własnych rodzinach. Migracja kobiet w większości obciążona jest dylematami związanymi z funkcją opiekuńczą, szczególnie jeśli chodzi o własne dzieci. Te i inne aspekty feminizacji migracji wypełniają treść artykułu.

\section{SKALA MIGRACJI KOBIET}

Migracje kobiet w skali całego globu przybierają na sile. Kluczowym rokiem był 2005 , w którym to kobiety stanowiły $49 \%$ wszystkich osób migrujących.

Dr hab. TERESA ZBYRAD, prof. UP - Instytut Filozofii i Socjologii Uniwersytetu Pedagogicznego im. KEN w Krakowie; e-mail: tzbyrad@interia.pl

${ }^{1}$ Za chlebem $i$ wolnościq. 200 lat nieprzerwanej migracji z ziem polskich, „Pomocnik Historyczny Polityki" 2018, nr 4.

2 Z. KawczyńsKa-Butrym, Migracje. Wybrane zagadnienia, Warszawa 2009, s. 39. 
Skala emigracji zarobkowej kobiet i jej dynamika są cechą dopiero XXI wieku³ To wcale nie znaczy, że w przeszłości kobiety nie migrowały. Wręcz przeciwnie, jednak zasadniczą różnicę stanowiła skala migracji (liczebność migrujących kobiet była zdecydowanie mniejsza), jak i jej przyczyny.

Roczniki statystyczne GUS ukazują migracje Polaków jednak tylko te długookresowe, tj. trwające dłużej niż rok (12 miesięcy i więcej). W związku z tym należy przypuszczać, iż skala migracji kobiet w celach zwłaszcza zarobkowych jest zdecydowanie większa, biorąc pod uwagę wyjazdy na prace sezonowe i trwające krócej aniżeli rok. Według danych $\mathrm{GUS}^{4}$, w 2013 roku liczba kobiet migrujących wyniosła 33170 i przekroczyła liczbę migrujących mężczyzn 33 127. Rok później tendencja była już odwrotna, tj. więcej mężczyzn wyemigrowało, łącznie 28 939, aniżeli kobiet - 26 021. Podobnie było w 2010 roku, kiedy odnotowano przewagę mężczyzn (wyemigrowało 20 773) nad kobietami $(20$ 443). Rok 2013 zasłynął też największą liczbą migracji zagranicznych, ogółem wyemigrowało pond 66 tysięcy osób (dokładnie 66 297). W następnym roku liczba migrantów spadła o ponad 11 tysięcy, wynosząc 54960 osób. Biorąc pod uwagę wiek migrujących kobiet, najwięcej z nich - $\mathrm{i}$ to jest szczyt migracji - migruje w wieku 30-44 lata. W tym przedziale wiekowym w 2013 roku wyemigrowało 12656 kobiet oraz 12230 mężczyzn. Druga pod względem wiekowym grupa kobiet migrujących przypada na wiek 25-29 lat. W 2013 roku wśród migrantów było prawie 5 tysięcy kobiet (4991), podczas gdy mężczyźni stanowili niecałe 4,5 tysiąca (4383). Trzecia fala migracji kobiet obejmuje wiek 45-59 lat. W tym wieku wyjechało więcej mężczyzn (5025) aniżeli kobiet (4834), jednak biorąc pod uwagę ich liczbę, jest ona nadal znacząca. Dane statystyczne wskazują, że kobiety zarówno te najmłodsze, tj. 18-24 lata, jak i te najstarsze, tj. 60 lat i więcej, emigrują w mniejszym stopniu aniżeli mężczyźni.

Ostatnie lata pokazują, iż kobiety migrują nie tylko czasowo, ale także decydują się na pobyt stały. Z danych GUS wynika, że od 2010 roku liczba kobiet (9385) przewyższa liczbę mężczyzn (7975). Rekordowy był 2013 rok, gdzie przewaga ta była o ponad 2,3 tys. (wyemigrowało 17229 kobiet, zaś 14874 mężczyzn). W 2014 roku te dysproporcje znacznie się zmniejszyły i wynosiły już tylko o 474 kobiet więcej ${ }^{5}$. Biorąc pod uwagę poszczególne kontynenty, tylko na jednym w skali globalnej zauważa się przewagę migrujących kobiet nad mężczyznami, i jest nim Europa. Spośród wszystkich krajów europejskich rekordy należą do Ukrainy, z której w 2010 roku 66,6\% emigrantów stanowiły kobiety, zaś w 2014 dyspro-

\footnotetext{
3 Tamże.

${ }^{4}$ Rocznik Statystyczny GUS, Warszawa 2016, s. 224.

5 Tamże, s. 225.
} 
porcja ta wynosiła $60,4 \%$. Na drugim biegunie są państwa, w których zauważa się znaczną przewagę migrujących mężczyzn. Spośród krajów europejskich wymienić można Norwegię, gdzie w 2010 roku kobiety migrujące stanowiły 38,2\%; następnie Holandię - 39,5\%, Danię - 41,2\% oraz Irlandię - 45,4\%. Rok 2014 przyniós nieznaczne wzrosty owych dysproporcji z większym udziałem kobiet. Wyjątek stanowi Irlandia, w której liczba kobiet migrujących zmniejszyła się w ciągu 4 lat, osiągając w 2014 roku wskaźnik 43,3\%6.

Migracje zagraniczne Polaków nasiliły się wraz z wejściem do Unii Europejskiej. Rok 2004 był kluczowy, gdyż otworzyły się granice i obywatele polscy uzyskali prawo do swobodnego przemieszczania się. Szacuje się, że w latach 2004-2016 do krajów europejskich wyjechało 1,2 mln Polaków. Według danych GUS, pod koniec 2016 roku za granicą przebywało $2,5 \mathrm{mln}$ polskich obywateli, $\mathrm{z}$ czego nieco ponad $2 \mathrm{mln}$ na terenie krajów $\mathrm{UE}^{7}$. Biorąc pod uwagę rozmieszczenie Polaków w poszczególnych krajach UE, pod koniec 2011 roku najwięcej Polaków przebywało w Wielkiej Brytanii (700 tysięcy), Niemczech (504 tysiące), Irlandii (123,9 tysiące) oraz Włoszech w liczbie blisko 111 tysięcy osób ${ }^{8}$. Joanna Kozielska na podstawie badań Polaków przeprowadzonych w Wielkiej Brytanii podaje, iż co trzeci mężczyzna i co czwarta kobieta przybyli na Wyspy Brytyjskie przed przystąpieniem Polski do Unii Europejskiej, np. w okresie powojennym, i pozostawali bierni zawodowo. Emigranci poakcesyjni, według autorki, w zdecydowanej większości są aktywni zawodowo, dotyczy to 95\% mężczyzn i $80 \%$ kobiet. Decyzja o opuszczeniu ojczyzny w sytuacji migracji poakcesyjnych nie jest jednorazowa, definitywna, istnieje możliwość rychłego powrotu. Poza tym migracje trzeciej generacji dotyczą ludzi młodych, którzy wchodzą w dorosłe życie, będąc w wieku największej produktywności. Migracje te wyróżniają się także poziomem wykształcenia migrantów - osoby młode, dobrze lub bardzo dobrze wykształcone, posiadające wysoki poziom kapitału społecznego oraz kulturowego. Ten rodzaj migracji, zwany także migracjami nowymi, jest domeną ostatniej dekady, dzięki ułatwieniom komunikacyjnym oraz prawnym umożliwiającym zmianę miejsca pobytu?

Badacze problematyki szacują, iż 1 maja 2004 roku skutkował jedną z największych fal migracyjnych w historii Polski. Także skutki tej fali migracji są obszerne

6 Tamże, s. 226.

${ }^{7}$ M.P. GaRAPICH, Życie na huśtawce. Londyńczycy. Nowy rodzaj migracji po wejściu Polski do Unii Europejskiej, w: Za chlebem i wolnościa, s. 124.

${ }^{8}$ M. Szast, Migracje wczoraj i dziś. Problematyka migracji przedakcesyjnych i poakcesyjnych z Polski, „Studia Polonijne” 37(2016), s. 17.

9 J. KozIElsKa, Poakcesyjne migracje zarobkowe. Kontekst teoretyczno-empiryczny. Wsparcie społeczne, Poznań 2014, s. 74, cyt. za: M. Szast, Migracje wczoraj i dziś, s. 19. 
i zapewne będą bardziej widoczne w przyszłości. Jak zauważa Michał Garapich: „Z socjologicznego, ekonomicznego i politycznego punktu widzenia skutki tej fali są ogromne; wywracają do góry nogami to, co wcześniej historycy i socjolodzy myśleli i pisali o polskich migracjach. Być może przyszli badacze właśnie akcesję do UE uznają za moment przełomowy, który spowodował, iż podział na polskie społeczeństwo i zagranicę, na Polaków i Polonusów uległ zatarciu, a tradycyjne instytucje, wokół których w przeszłości organizowało się życie polskie od Berlina po Chicago - Kościół, organizacja polonijna, szkoła polska - przestaną sprawować swoje funkcje" ${ }^{\prime 10}$. Nie bez znaczenia w ocenie skutków migracji będzie rosnący udział kobiet $\mathrm{w}$ procesach migracyjnych. Zjawisko migracji zarobkowej kobiet niespotykane na taką skalę jak obecnie, odciśnie swoje piętno szczególnie na kraju pochodzenia, pozostawiając wyrwę w społeczeństwie i rodzinie.

\section{MIGRACJE KOBIET DAWNIEJ I DZIŚ}

Współczesna fala migracji kobiet, a zwłaszcza przyczyny i cel migracji są wydarzeniem bez precedensu. Sam fakt kobiety na emigracji nie budzi zdziwienia, jednak skala zjawiska i przyczyny są zupełnie inne niż w przeszłości. Można zaryzykować tezę, iż kobiety od zawsze miały swój udział w procesach migracyjnych. Jednak owe migracje nie były zarobkowe, ale wiązały się z konkretnym celem pozamaterialnym, a nawet misją. Kiedy sięgniemy do Starego Testamentu, w wędrówce prowadzonej przez Mojżesza do Ziemi Obiecanej obecne są kobiety jako żony, matki czy córki. Towarzyszyły one swoim mężom w wędrówce przez 40 lat. Nie wiemy dokładnie, ile kobiet wędrowało, gdyż w owym czasie nawet nie spisywano kobiet. Mamy tylko informację o mężczyznach: „Oto Izraelici spisani według swoich rodów. Wszystkich spisanych w obozach według ich zastępów było sześćset trzy tysiące pięćset pięćdziesięciu"ll. W Księdze Wyjścia nie znajdujemy szerszych informacji o kobietach, ich roli czy problemach, z jakimi się zmagały podczas wędrówki poza jednym wyjątkiem - Miriam, która pociągnęła za sobą inne kobiety śpiewając pieśń dziękczynną: „Miriam, prorokini, siostra Aarona, wzięła bębenek do ręki, a wszystkie kobiety szły za nią w pląsach i uderzały w bębenki. A Miriam przyśpiewywała im: «Śpiewajmy pieśń chwały na cześć Pana, bo swą potęgę okazał, gdy konie i jeźdźców ich pogrążył w morzu»" ${ }^{\text {"2 }}$. Postawa

\footnotetext{
${ }^{10}$ M.P. GARAPICH, Życie na huśtawce, s. 124-125.

${ }^{11}$ Księga Liczb (2,32). Pismo Święte Starego Testamentu.

${ }^{12}$ Księga Wyjścia $(15,20)$. Pismo Święte Starego Testamentu.
} 
tej kobiety wzbudziła zapewne zachwyt, skoro została zauważona; zrobiła coś co godne było odnotowania.

Z dostępnych źródeł historycznych wynika, iż na przestrzeni dziejów motywy i cele migracji kobiet znacznie różniły się od współczesnych. Zmieniały się także ich źródła utrzymania. W związku z tym warto zrobić krótki przegląd obecności kobiety w procesach migracyjnych, zwracając szczególną uwagę na uwarunkowane przyczynami typy migracji.

Pierwsze wzmianki o migracji kobiet pochodzą z czasów średniowiecznych. Były to migracje głównie w celach matrymonialnych. Niemal od samego początku istnienia państwa polskiego władcy piastowscy brali za żony księżniczki pochodzące z zagranicy. Na tronach polskich spośród wielu obcych księżniczek były i takie pochodzące z dalekich - jak na ówczesne czasy - stron. Przykładem jest opolska księżna Viola, która według opisu Jana Długosza pochodziła z Bułgarii ${ }^{13}$. Migracje kobiet $\mathrm{w}$ celach matrymonialnych miały również charakter polityczny. Zwraca na to uwagę Ilona Matejko analizując herby rodowe. Jak podaje autorka, ubogaceniem na pieczęci herbu w czasach średniowiecznych było dodanie symboli innego, najczęściej pochodzącego z rodowodu żony, co umacniało pozycję władcy. Poprzez mariaże zacieśniano także kontakty z innymi: „Układy tego typu miały zarówno w okresie średniowiecza, jak i w czasach nowożytnych głównie charakter polityczny, gdyż służyły władcom do umacniania zawiązanych między sobą sojuszy"14.

Przełom XVI-XVIII wieku przyniósł pewne zmiany w migracji kobiet. Chociaż nadal do głównych należały motywy związane z zamążpójściem, to jednak obok nich pojawiały się inne. Źródłem wiedzy w tym zakresie są pamiętniki staropolskie pisane przez szlachtę, a dosadnie rzecz ujmując - „memuary mężczyzn, którzy pisali dzienniki, kierując się potrzebami utrwalenia wydarzeń, spisania dziejów rodziny, własnych, a nawet ku edukacji młodzieży"15. Z pamiętników wyłania się podział na emigracje krótkotrwałe i długoterminowe, trwające od kilku tygodni do kilku miesięcy lub lat. Migracje długoterminowe wiązały się na ogół z zamążpójściem, pracą męża, przyjętą przez kobietę posadą, zostania rezydentką lub damą do towarzystwa, odejściem z domu męża po jego śmierci, usunięciem się w cień z innych względów. W tamtym okresie rolę kobiety wyznaczał status społeczny

13 A. Pobóg-Lenartowicz, Viola, Bułgarka, Księżna Opolską. Przyczynek do migracji matżenskich $w$ średniowieczu, w: Kobiety i procesy migracyjne, red. A. Chlebowska, K. Sierakowska, Warszawa 2010, s. 11.

${ }^{14}$ I. МАтеJко, Herby rodowe jako przejaw migracji matżeńskich na pieczęciach księżnych legnicko-brzeskich, w: tamże, s. 20-21.

${ }^{15}$ R. GAŁAJ-DEMPNIAK, Migracje kobiet zamężnych w świetle pamiętników staropolskich pisanych przez szlachtę, w: tamże, s. 29. 
męża i możliwości ekonomiczne rodziny. Samotne szlachcianki wiodły ciężki żywot na łaskawym chlebie krewnych, o ile nie poszły do klasztoru. Migracje czasowe mogły rozciągać się od kilku tygodni, miesięcy a nawet lat, w zależności od przyczyny. Wśród przyczyn w pamiętnikach wymieniano: poród i poszukiwanie lepszej opieki medycznej, niesienie pomocy potrzebującym krewnym, konieczność poddania się kuracji medycznej, ucieczka przed zarazą, wojną, pielgrzymki, sejmy, trybunały, święta, podjęcie pracy w trudnym czasie (np. pomoc mężowi w utrzymaniu rodziny), niewola, bycie wychowanką, banicja nałożona na męża, wyjazd $\mathrm{w}$ interesach i udział w uroczystościach ${ }^{16}$. Podobnie jak w poprzednich wiekach, zamążpójście było główną przyczyną migracji kobiet, obowiązywała zasada, że kobieta przeprowadza się do domu męża. Po ślubie zdarzało się, iż w poszukiwaniu lepszego standardu życia małżonkowie przeprowadzali się do innych posiadłości. Warto podkreślić, iż wśród kobiet niejako skazanych na migracje znaczne grono stanowiły kobiety samotne (stare panny), jak i wdowy. Brak możliwości zarobkowych sprawiał, iż kobieta samotna skazana była na „łaskę” krewnych bądź też przydzielano jej status rezydentki. W analizowanym okresie znana była służba „mamki”. Jak wynika z pamiętników, wywodziły się one najczęściej z pobliskich wsi, ale te najlepsze: „które dobrze dbały o dzieci, polecano sobie nawzajem i sprowadzano nawet z odległych okolic. Niańki bywały nierzadko szlachciankami" ${ }^{17}$. Najbardziej oddane i zasłużone nianie przemieszczały się z dworu do dworu, co było w pewnym sensie ,życiem” na migracji.

Falę migracji stałej, głównie europejskiej i zamorskiej, datuje się na lata 70. XIX wieku. Termin „stała” nie oznaczał, że wyjeżdżający opuszczali kraj na zawsze. Chodziło raczej o podkreślenie różnicy wobec migracji sezonowej. Migracje stałe trwały najczęściej rok i miały na celu zgromadzenie kapitału, który po powrocie do ojczyzny pozwolił prowadzić dostatnie życie ${ }^{18}$. Rysem charakterystycznym migracji była „kultura samotnych mężczyzn”. Taki termin wprowadziła Alina Witkowska, określając polistopadową emigrację. $Z$ danych źródłowych wynika, iż zaledwie kilku procentom wychodźców towarzyszyły żony. Wiosną 1832 roku we Francji znalazło się 1173 Polaków, którym towarzyszyło 10 kobiet, w tym 22 dzieci $^{19}$. W XIX wieku, po klęsce powstania, mężczyźni wędrowali jako wojskowi: oficerowie i podoficerowie; szeregowi, politycy (członkowie rządu), a nawet dziennikarze. Jak podaje Małgorzata Karpińska, „kultura samotnych mężczyzn” kształtowała obraz obyczajowości i dnia codziennego emigrantów. Deficyt kobiet

\footnotetext{
16 Tamże, s. 29-30.

17 Tamże, s. 36.

18 W. MęDRzeCKI, My naród emigrantów, w: Za chlebem $i$ wolnością, s. 7.

${ }^{19}$ A. Kożuchowski, Wielka Emigracja, w: Za chlebem $i$ wolnościa, s. 19.
} 
(zwłaszcza Polek) na emigracji sprawiał, iż kobieta była nie tylko bliską osobą, ale stawała się synonimem utraconej ojczyzny, dawnego sielskiego, spokojnego, przeważnie względnie dostatniego życia. Z biegiem czasu ukształtował się wyidealizowany obraz kobiety Polki - najlepszej matki, a największym marzeniem mężczyzny było zdobycie żony Polki. Kobieta Polka na emigracji, towarzysząca mężczyźnie, wpisywała się w stereotyp cichej, wiernej żony i gorliwej patriotki. To kobiety, czasem zupełnie nieświadomie, pełniły funkcje strażniczek narodowego ducha i tradycji, zwłaszcza wówczas, gdy organizowały tradycyjne obchody świąt Bożego Narodzenia lub Wielkanocy, częstowały polskimi potrawami, błogosławiły w godzinie decyzji, a nawet wtedy, kiedy „zamykały oczy w ostatniej chwili” ${ }^{20}$. Być może z tych względów polskie kobiety były tak cenione i pożądane na emigracji.

W czasach tzw. Wielkiej Emigracji mężczyźni rywalizowali ze sobą w „pogoni za kobietą". Ponieważ wolnych Polek było niewiele, więc pożądanie wzbudzały żony współtowarzyszy ${ }^{21}$. Toteż $\mathrm{w}$ jednym $\mathrm{z}$ pamiętników 23-letniego kapitana Zielińskiego czytamy: „Mąż za nic tu żony z Polakiem sam na sam nie zostawi”"22. Kobiety Polki były atrakcyjne dla mężczyzn jako żony i matki, troszczące się o dom i dzieci. Mężczyźni tęsknili za ojczyzną i kobietą z Polski, pragnęli założyć rodzinę z kobietą pochodzącą ze „swoich”. Jak podają źródła: „Na emigrację udawały się młode kobiety - zwykle do mężów lub narzeczonych, jako umówione korespondencyjnie kandydatki na żony dla mężczyzn, którzy postanowili ułożyć sobie życie w Nowym Świecie, ale z kobietą z porządnej rodziny z sąsiedztwa"²3.

$\mathrm{Z}$ perspektywy socjologii rodziny możemy ocenić, że tego typu związki małżeńskie na emigracji, kiedy Polak poszukiwał Polki, były typowym przykładem endogamii, polegającej na poszukiwaniu kandydatki na żonę wśród „swoich”. Takie praktyki były charakterystyczne dla chłopów jeszcze na początku XX wieku, wśród których do małżeństw dochodziło w obrębie tej samej wsi lub parafii. W prawie 90\% związków małżonkowie pochodzili z najbliższej okolicy. Ogromne znaczenie miała także przynależność do tej samej grupy narodowej oraz wyznaniowej. Ważnym czynnikiem była zgoda rodziców na zawarcie związku małżeńskiego ${ }^{24}$. U podstaw tak rozumianej endogamii było zachowanie wspólnej tradycji, kultury, religii, kultu przodków, zwyczajów i obyczajów, ale też utrzymanie majątku, np. ziemi na wsi położonej w najbliższej okolicy.

${ }^{20}$ M. KARPIŃSKA, Kobiety wielkiej emigracji - próba portretu socjologicznego, w: Kobiety i procesy migracyjne, s. 47-60.

${ }^{21}$ Tamże, s. 51.

22 A. Kożuchowski, Wielka Emigracja, s. 19.

${ }^{23}$ W. MęDrzecki, My naród emigrantów, s. 7.

${ }^{24}$ M. Dajnowicz, Migracje matżeńskie kobiet polskich na pograniczu pólnocno-wschodnim w poczatkach XX wieku, w: Kobiety i procesy migracyjne, s. 100-102. 
Historia migracji kobiet nie pozostawia wątpliwości, iż zarówno przyczyny, jak i cel migracji znacznie różniły się od współczesnych wzorów. Jeszcze na przełomie XIX i XX wieku kobiety uczestniczyły głównie jako żony i córki migrujących mężczyzn. Warto przypomnieć, iż w Królestwie Polskim oczekiwano od kobiety opuszczenia domu rodzinnego i podążania za mężem. Regulował to artykuł 210 prawa małżeńskiego, który głosił: ,żona obowiązana jest mieszkać z mężem i iść za nim wszędzie, gdzie mu się zostać podoba" ${ }^{25}$. Rola mężczyzny w migracjach była wiodąca, co wiązało się z dominującym modelem rodziny, w którym do obowiązków mężczyzny należało poszukiwanie źródeł utrzymania. Do roli kobiety zaś należało prowadzenie domu i wychowywanie dzieci. Taką też rolę pełniły kobiety migrujące wraz z mężem. Zdarzało się, że kobiety podejmowały prace, ale pod warunkiem pozostania w domu, np. kobiety zamężne prowadziły „stołówki” dla samotnie migrujących mężczyzn ${ }^{26}$.

Wiek XX przyniósł zasadnicze zmiany w przyczynach migracji kobiet. W latach I wojny światowej, obok nadal występującego motywu zamążpójścia (migracje ślubne i przedślubne - narzeczeńskie), pojawiły się migracje polityczne przymusowe związane z działaniami wojennymi, a nawet migracje o charakterze ekonomicznym, edukacyjnym czy zdrowotnym. Okres zaborów i działania wojenne powodowały, że kobiety wraz ze swoimi mężami wędrowały na Sybir bądź do Europy Zachodniej. Jak podają źródła: „W zależności od reprezentowanej opcji politycznej wędrowały pod opiekę Rosji lub Austro-Węgier, ewentualnie innych państw europejskich niezaangażowanych w konflikt zbrojny"27. Kobiety podczas migracji wspierały mężów duchowo, pomagały w działalności, organizowały życie towarzyskie, załatwiały wiele spraw, m.in. kobiety dzięki urokowi osobistemu potrafiły dostać się tam, gdzie nie mogli dotrzeć ich mężowie czy ojcowie. Wyjazdy ekonomiczne wiązały się głównie z zakupami, tj. nabywaniem produktów niedostępnych w okolicy. Kobiety były odpowiedzialne za zaopatrzenie w przedmioty codziennego użytku, jak i te o charakterze higienicznym, odzież, obuwie czy drobne rzeczy niezbędne do utrzymania rodziny i wyposażenia domu. Po zakupy zawsze udawały się w towarzystwie mężczyzn. Ponadto zdarzało się wśród ziemianek, iż niektóre z nich samotnie zarządzały majątkiem, a ich wyjazdy wiązały się z utrzymaniem gospodarstwa. Kolejne wyjazdy to edukacyjne. Od 1897 i 1900 roku kobiety miały możliwość studiowania na Uniwersytecie Jagiellońskim na dwóch z czterech istniejących wydziałów, tj. filozoficznym i lekarskim. Otrzymały także możliwość

${ }^{25}$ H. Konic, Prawo malżeńskie obowiązujące w b. Królestwie Kongresowym, Warszawa 1924, s. 200.

26 Z. KAwCZYŃSKA-Butrym, Migracje, s. 38-39.

27 U. OetTingen, Migracje ziemianek w latach I wojny światowej - uwarunkowania $i$ wplyw na styl życia, w: Kobiety i procesy migracyjne, s. 132. 
doktoryzowania się. W 1917 roku stopień doktora filozofii otrzymała pierwsza kobieta - Maria Godlewska-Radwańska. Coraz większe możliwości kształcenia się otwierane na różnych uczelniach spotęgowały migracje kobiet $\mathrm{z}$ różnych stron Polski. Wreszcie należy wspomnieć o migracjach zdrowotnych, które stanowiły jeden z głównych powodów zmiany miejsca pobytu. Chociaż - jak podają badacze problematyki - nie zawsze był to rzeczywisty powód wyjazdu, ale zawsze uwzględniany przez władze ${ }^{28}$.

Warto wspomnieć, iż tzw. migracje międzyzaborowe często wiązały się z poprawą i polepszeniem warunków życia. Jednak taki sposób przemieszczania „kłócił się” z pewnymi ideałami, a szczególnie „obowiązkami patrioty”. Postawę niezłomną w tym zakresie zachowała Eliza Orzeszkowa, która zrezygnowała z szansy przeniesienia się dla własnej wygody. Szerzej relacjonuje to Adam Kożuchowski: „Takie przenosiny w strony, gdzie oddychało się powietrzem choć trochę nasyconym wolnością, a także żyło dostatniej i swobodniej, nie zawsze licowały z etosem polskiego patrioty, któremu ideał tzw. pracy organicznej kazał trwać na posterunku i krzewić polskość, oświatę i kulturę, tam gdzie ich nie dostawało. Tak przynajmniej sądziła Eliza Orzeszkowa, odmawiając przenosin z prowincjonalnego i zrusyfikowanego Grodna do Warszawy, była bowiem przeciwniczką migracji do miejsc szczęśliwych. O ile madame Curie była usprawiedliwiona, bo jako panna Skłodowska swych odkryć nie mogłaby dokonać, to już Józef Korzeniowski ze swoją angielską sławą jako Joseph Conrad budził uczucia dwuznaczne - talent mógł przecież obrócić na korzyść własnej ojczyzny"29. Zatem migracja w poszukiwaniu lepszego życia była czymś nagannym, co przeczyło ideałom patriotycznym, była swoistą ucieczką od trudnej sytuacji w kraju, ucieczką od zobowiązań. Jedynym usprawiedliwieniem w myśl krzewionych ideałów była niemożność rozwoju we własnym kraju.

Po II wojnie światowej nasiliły się migracje związane z przymusowym wysiedleniem. Ten rodzaj migracji spowodował rozbicie i osłabienie potencjału społecznego, wyniszczenie fizyczne oraz pozbawienie niemal całości dóbr materialnych. Przesiedlenia i deportacje, którym towarzyszyły ekstremalne warunki transportu i życia, powodowały także fizyczną eksterminację ludności. Zarówno transport, jak i ciężka praca, zwłaszcza Polaków z odległych terenów Rosji były opisywane we wspomnieniach: „My, wycieńczone kobiety, dźwigałyśmy podkłady kolejowe przy budowie magnitogorskiej magistrali. Ludzie umierali na dur i tyfus plamisty. Przeżyliśmy gehennę "30. Jak podaje Barbara Kubis, analizująca wspomnienia kobiet

\footnotetext{
28 Tamże, s. 136-141.

29 A. Kożuchowski, Wielka Emigracja, s. 18.

${ }^{30}$ Z. KAwCZYŃSKA-Butrym, Migracje, s. 25-26.
} 
$\mathrm{z}$ tamtych lat, kobiety pozbawione rodzinnej ziemi zostały zmuszone do kolejnej zmiany. Były to kobiety wykonujące różne zawody i wywodzące się z różnych środowisk społecznych: pisarki, publicystki, nauczycielki, lekarki, proste wiejskie kobiety i robotnice z fabryk, dziewczyny i samotne matki. Wszystkie one musiały zmagać się z trudną powojenną rzeczywistością. Walczyły o życie i przeżycie, ponieważ ich ojcowie bądź mężowie poszli na wojnę. Brakowało ojców, mężów, braci, którzy nie wracali z frontu, niewoli, pozostawali w więzieniach, obozach czy szpitalach. Były to czasy ciężkiej pracy, cierpienia i głodu. Gdy wojna się skończyła, rzeczywistość powojenna była równie straszna: „zawalone domy, ruiny, krzyże. Bardzo często nikt na te kobiety nie czekał, nie cieszył się, że przeżyły, nie witał po powrocie. Trzeba było jednak żyć, działać, licząc instynktownie na życzliwość losu"31.

Pomimo prowadzonych działań wojennych i wymuszonych migracji politycznych czy przesiedleńczych, nie ulega wątpliwości, iż XX wiek zapisał się na kartach historii jako wiek emigracji zarobkowej. Źródła podają, iż lata 80. i 90. XIX wieku to okres nasilonego wychodźstwa z ziem polskich i masowej emigracji zarobkowej m.in. do Ameryki Północnej i Południowej. Przed I wojną światową liczebność polskiej emigracji w Ameryce Północnej szacowano na około 3 mln osób, z czego prawie połowa skupiła się w trzech stanach, tj. Nowym Jorku, Pensylwanii i Illinois. Wśród uchodźców głównie chłopów, rzemieślników i robotników niewykwalifikowanych znajdowały się kobiety: matki, żony i córki ${ }^{32}$. W latach 30 . XX wieku rozwinęła się żegluga morska przewożąca rzesze migrantów. W okresie 1936-1939 kursowało sześć regularnych linii oceanicznych przewożących migrantów z Polski, tj. „Polonia”, „Kościuszko”, „Batory”, „Piłsudski”, „Sobieski” i „Chrobry”. Klasa I i II była na ogół turystyczna, zaś klasa III emigracyjna, oferująca w „Polonii”, „Sobieskim” i „Chrobrym” ponad 800 miejsc dla pasażerów-migrantów ${ }^{33}$.

Migracja kobiet do Ameryki miała też swoje ciemne strony. Warto przywołać kwitnący już od końca XIX wieku handel kobietami. Jak podaje Andrzej Krajewski, białe kobiety, zwłaszcza o jasnej karnacji, w Ameryce Południowej stanowiły egzotykę. Płacono ogromne sumy za ich usługi seksualne. Właściciele domów publicznych oferowali nawet 10 tys. niemieckich marek za dostarczenie jednej urodziwej Słowianki. W Ameryce Południowej istniała cała organizacja handlowa skierowana ku przewozowi białych niewolnic z krajów Starego Świata. Organizacja o charakterze mafijnym nazywana była Warszawą. Jej zręby tworzył Żyd

${ }^{31}$ B. KuBIs, Wpływ przymusowych migracji na powojenne losy kobiet polskich $-w$ świetle wspomnień, w: Kobiety i procesy migracyjne, s. 184-186.

32 Z. Chyra-Rolicz, Zwiazek Polek w Ameryce, w: tamże, s. 207.

33 T. ZAWADZKI, Na fali. Masowe wyjazdy zarobkowe wplynęty na rozwój polskiej żeglugi, w: Za chlebem i wolnościa, s. 52-53. 
z Łodzi - Noe Trauman, a do świetności doprowadził inny emigrant z Królestwa - Zvi Migdal. Wszelkie próby walki z organizacją kończyły się fiaskiem. Zyski z działalności pozwalały na skorumpowanie lokalnej policji oraz władz, aby nie przeszkadzały w niewolniczym procederze. Dopiero narodziny II Rzeczypospolitej przyniosły nadzieję na ukrócenie masowych uprowadzen ${ }^{34}$.

W połowie XX wieku sytuacja polityczna w naszym kraju stała się motorem różnego typu migracji. Ludzie migrowali w warunkach ograniczonej wolności, z przyczyn politycznych, w ucieczce przed władzą, przed prześladowaniem, a także nadal były popularne wyjazdy ,za chlebem”, czy nawet z pobudek rasowych. Szczególne piętno odcisnął marzec 1968 roku. Według danych źródłowych, przyczynił się on do wyjazdu do Szwecji grupy emigrantów. Szacuje się, że osiedliło się tam ponad 2 tysiące obywateli polskich najczęściej pochodzenia żydowskiego ${ }^{35}$. Lata 70. przyniosły kolejną falę migracji, w której znaleźli się uchodźcy polityczni. $\mathrm{Z}$ uwagi na ułatwienia komunikacyjne i zniesienie obowiązku wizowego do Szwecji, ruszyły grupy pracowników sezonowych, a wśród nich studenci. Charakterystyczny dla tego okresu jest napływ Polek, które zawierały małżeństwa z obywatelami szwedzkimi. Podłożem tych decyzji była poprawa warunków materialnych i zabezpieczenie sobie lepszej przyszłości w zamożnej Szwecji. Dlatego tak zwana emigracja matrymonialna, inaczej określana jako „erotyczna”, miała także wymiar ekonomiczny. Polki korzystały z biur matrymonialnych, a interesowali się nimi nade wszystko Szwedzi pochodzący z niższych warstw społecznych. Z badań wynika, że 70\% kobiet traktowało małżeństwo ze Szwedem jako formę polepszenia warunków życia ${ }^{36}$.

Lata 70. i 80. przyniosły turystykę handlową. Popularne były wyjazdy do NRD i ZSRR. Obok zwykłych migracji ,po towar”, pojawiły się zjawiska patologiczne, jak np. prostytucja i przemyt ludzi. Handel ludźmi najczęściej obejmuje handel kobietami. Zasadą obowiązującą jest dostarczanie kobiet do krajów i rejonów bogatszych niż ich kraj pochodzenia. Do krajów Europy Zachodniej sprowadza się nawet kobiety z krajów Trzeciego Świata. Według badaczy problematyki: „Polki były pierwszymi kobietami sprowadzonymi z Europy Wschodniej”" ${ }^{37}$. Raporty Handlu Ludźmi z 2006 roku opracowane przez rząd Stanów Zjednoczonych donoszą, iż co roku od 600 do 800 tysięcy mężczyzn, kobiet i dzieci przekracza granice

34 A. Krajewski, Polaca czyli prostytutka. Domy publiczne w Ameryce Poludniowej przed stu laty pękaty $w$ szwach od kobiet uprowadzonych z ziem polskich, w: tamże, s. 40-41.

35 A. KıonczyŃsKi, Polki w Szwecji w latach 1945-1980. Emigracja polityczna, ekonomiczna i matrymonialna, w: Kobiety i procesy migracyjne, s. 263.

36 Tamże, s. 264.

37 Z. KawCZYŃSKA-Butrym, Migracje, s. 25-26. 
swojego kraju jako ofiary handlu ludźmi. Spośród nich aż 80\% stanowią kobiety, a ponad połowa z nich ma mniej niż 18 lat $^{38}$.

Wyjazdy migracyjne zwłaszcza w okresie PRL-u doczekały się wielu produkcji filmowych z kobietami w tle. Jednym z bardzo wymownych był film nakręcony w 1978 roku przez Jerzego S. Stawińskiego „Bilet powrotny”. Ukazuje on kobietę zdolną do poświęceń za wszelką cenę, aby tylko polepszyć byt ekonomiczny ukochanego syna. Kobieta przyjeżdża do wuja do Kanady, podejmuje się najcięższych prac, m.in. wybiera kamienie $\mathrm{z}$ wykarczowanych pól. Po czym dla pieniędzy wychodzi za Francuza, z którym nic ją nie łączy, a nawet nie zna języka. Syn przysyła z Polski zdjęcia domagając się coraz więcej pieniędzy na rzekomą budowę domu. Matczyna miłość i poświęcenie nie zna granic. Powrót do Polski staje się gorzki, gdyż syn przepuścił wszystkie pieniądze, a zdjęcia z budowy domu były od sąsiada ${ }^{39}$. Ta filmowa siłaczka nie jest tylko oderwaną od rzeczywistości opowiastką. Wiele kobiet na emigracji podejmuje się nawet bardzo ciężkich prac, znosi upokorzenia, aby podnieść standard życia swoich bliskich, a szczególnie dzieci.

Okres transformacji ustrojowej w Polsce przyniósł upragnioną wolność i możliwości opuszczania granic. Migracje nasiliły się i doczekały kolejnej typologii na te przedakcesyjne (przed przystąpieniem do UE) i poakcesyjne. Jak podaje Mateusz Szast, migracje przedakcesyjne to tzw. migracje stare, wojenne, związane z wyjazdami o pobudkach politycznych, mających na celu przeczekanie czasów Stalina i komunizmu. Migranci przedakcesyjni nie kierowali się pobudkami ekonomicznymi. Z kolei migracje poakcesyjne to migracje nowe, związane $\mathrm{z}$ otwarciem granic Unii Europejskiej 1 maja 2004 roku. Otwarte rynki pracy zwłaszcza w takich krajach, jak Wielka Brytania, Irlandia, Szwecja, ale też Dania, Holandia, Norwegia, Finlandia, Islandia czy Włochy - wzmogły procesy migracyjne do tych krajów. W przypadku migrantów poakcesyjnych decyzja o wyjeździe nie jest już jednorazowa, definitywna, gdyż migranci przewidują możliwość powrotu bądź zmiany kraju pobytu. Migracje poakcesyjne są najczęściej zarobkowe. Większość migrantów to ludzie młodzi, w wieku aktywności zawodowej: 95\% mężczyzn i $80 \%$ kobiet $^{40}$.

Przystąpienie Polski do UE zmieniło sytuację migrantów. Zmiana ta była dość istotna, obejmowała warunki pracy. $Z$ relacji kobiet przebywających na migracji we Włoszech wynika, że przed akcesją najczęściej pracowały „na czarno” - bez formalnego zatrudnienia: „Cały czas tutaj pracowałam na czarno, bo jeszcze przed

38 Tamże, s. 35.

39 Zob. R. WŁodeK, Z kamera na Greenpoincie. Nostalgicznie, komediowo, bezlitośnie - jak emigrantów pokazano w filmach, w: Za chlebem i wolnościa, s. 117.

${ }^{40}$ M. Szast, W Irlandii wygodniej, ale w Polsce lepiej. Kapitat społeczno-kulturowy i ocena sytuacji życiowej polskich migrantów w Irlandii, Lublin 2017, s. 93-97. 
wejściem do UE i zrobienie dokumentów było prawie fizyczną niemożliwością. Pracowałam na czarno jako kelnerka, jako sprzątaczka, jako opiekunka do osób starszych"41.

Kobiety poza granicami kraju często doznają czegoś, co określa się mianem „szoku kulturowego". Oto wybrane zeznania kobiet przebywających we Włoszech: „U nas kobieta, która ma 65 lat, to jest stara kobieta, a tutaj szuka się narzeczonego, jak się nie ma męża”; „Kobiety, które przyjeżdżają tutaj mogą czuć się zszokowane, bo chłop idzie, albo zacznie gwizdać, albo powie «ciao bella», w każdym razie jakoś zwróci uwagę, mrugnie okiem. To może być na początku trochę krępujące i trochę takie... brak mi słów"42.

Reasumując migrację niegdyś i współcześnie, zauważyć można istotne zmiany. Do głównych należą: motywy migracji, typy i stopień zależności. Kobiety dawniej migrowały z mężem lub do męża, najczęściej był to bilet w jedną stronę. Obecnie migrują same, są niezależne ekonomicznie, ale też niekiedy zdane same na siebie. Współczesne kobiety są mobilne. Zmieniają miejsca migracji w zależności od własnych upodobań. Migrują nawet wówczas, gdy ich mężowie czy dzieci pozostają w domu, w Polsce. To pewna zmiana, która nigdy wcześniej nie miała miejsca. Warto więcej uwagi poświęcić obecnej migracji kobiet.

\section{PRZYCZYNY MIGRACJI KOBIET WE WSPÓŁCZESNYM ŚWIECIE}

Migracje zarobkowe (ekonomiczne) należą do kluczowych wśród wszystkich przyczyn migracji. Kierują się nimi zarówno kobiety, jak i mężczyźni. I chociaż nikogo nie dziwi fakt, że mężczyźni podążają do innych krajów w celach zarobkowych, to jednak w przypadku kobiet postawić należy znak zapytania.

Doszukując się przyczyn podążania za pracą przez kobiety na emigracji, należy sięgnąć do zmian, jakie nastąpiły w małżeństwie i rodzinie. Sięgając wstecz kilka wieków temu, panował powszechnie model rodziny tradycyjnej, w której to mężczyzna był odpowiedzialny za utrzymanie rodziny, zaś do obowiązków kobiety należała troska o dzieci, męża i gospodarstwo domowe. Zachwianie tego modelu nastąpiło wraz z procesem industrializacji, umożliwiającej podjęcie pracy zawodowej przez kobietę. Przemiany w środowisku pracy pociągnęły za sobą przemiany w środowisku życia, a szczególnie w rodzinie. Zmienił się układ ról i pozycji. Mężczyzna przestał był głową rodziny. Część jego obowiązków przejęła kobieta,

\footnotetext{
${ }^{41}$ Z. KawCZYŃSKa-ButrYM, Migracje, s. 105-106.

42 Tamże, s. 82.
} 
w tym odpowiedzialność za utrzymanie rodziny ${ }^{43}$. Model mężczyzny - żywiciela jest współcześnie wyjątkiem nie regułą. Kobiety stały się niezależne ekonomicznie. W wielu gospodarstwach domowych stosunki partnerów są bardziej egalitarne. Badania wskazują, iż odpowiedzialność za budżet domowy uwarunkowany jest sytuacją materialną danej rodziny. I tak wśród par uzyskujących wyższy dochód, środki finansowe stanowią wspólną pulę i wspólnie prowadzony jest budżet rodzinny. $\mathrm{Z}$ kolei w rodzinach $\mathrm{z}$ niższym dochodem kobiety często odpowiadają za codzienne wydatki, ale niekoniecznie uczestniczą w podejmowaniu strategicznych decyzji odnośnie do budżetu i wysokości wydatków. W takich przypadkach kobiety chronią dostęp swoich mężów do pieniędzy, same pozbawiając się prawa do planowania wydatków ${ }^{44}$. Należy zatem stwierdzić, iż redefinicja roli mężczyzny w rodzinie i zmiana pozycji kobiety w rodzinie doprowadziły do sytuacji, w której kobieta czuje się odpowiedzialna za dostarczenie środków utrzymania, zaś mężczyźni coraz częściej zwalniają się z tego obowiązku.

W społeczeństwach, w których nadal utrzymywany jest tradycyjny model rodziny, w której to mężczyzna ponosi odpowiedzialność za środki utrzymania, kobiety nie migrują $\mathrm{w}$ celach zarobkowych. Taki model nadal jest utrzymywany we Włoszech. Polki tam zatrudnione najczęściej w pracach opiekuńczych budzą powszechne zdziwienie. Oto jedna z wypowiedzi: „Kobieta włoska uważa, że w Polsce nie ma mężczyzn (bo mężczyzna ma pracować na rodzinę). Nie wyjechałaby za granicę, nie zostawiłaby swoich dzieci, żeby pracować, żeby je utrzymać. Ona by męża wykopała wszystkimi butami z ostrym czubkiem, żeby pojechał szukać pieniędzy, a ona by była z dziećmi" ${ }^{\text {}}$. Jest to dość smutny portret kobiety Matki-Polki tułającej się za granicą, aby zarabiać pieniądze na utrzymanie rodziny.

Migrację zarobkową kobiet określa się jako „migrację przeżycia”. Świadczą o tym zeznania kobiet uzasadniające konieczność wyjazdów: „na życie, naukę dla dzieci, spłatę długów". Natomiast mężczyźni wyjeżdżają najczęściej, by podwyższyć standard życia, np. kupić samochód, wyremontować dom czy mieszkanie. Kobiety migrujące za pracą częściej niż mężczyźni mają dzieci do 18 roku życia, a nawet małe, poniżej 7 lat ${ }^{46}$.

Migracje przeżycia ukazują dość trudną sytuację kobiet mających dzieci, a pozbawionych bezpieczeństwa ekonomicznego. Jest to spuścizna feminizmu doprowadzająca do tak daleko posuniętej niezależności kobiet, że paradoksalnie im zagrażającej. Kobiety znalazły się w pewnej pułapce $\mathrm{z}$ jednej strony uwolnienia od

\footnotetext{
${ }^{43}$ F. AdAmski, Rodzina. Wymiar społeczno-kulturowy, Kraków 2002, s. 141-143.

44 A. Giddens, Socjologia, Warszawa 2004, s. 421-422.

45 Z. KawCZyŃsKa-Butrym, Migracje, s. 104.

46 Tamże, s. 48-49.
} 
tradycji i prawa do decydowania o sobie samej, a z drugiej - pozostawione same sobie, niemogące liczyć na pomoc ojców dzieci, zniewolone pracą, aby utrzymać rodzinę. Trafnie wpływ feminizmu na rodzinę ujmuje Małgorzata Biedroń, zadając pytanie: „Czemu winny jest feminizm?”. Autorka stawia wiele zarzutów pod adresem feminizmu, m.in. takie, że: kobiety stały się mniej delikatne; nie chcą być żonami; podejmują działania do tej pory dla nich niedostępne; rywalizują ze swoimi mężami; kobiety mogą wybierać style życia dotychczas niedostępne; nastąpiła redefinicja ról społecznych i rodzinnych kobiety. Winą feminizmu jest także to, że kobiety doświadczają frustracji; poszukują szczęścia i samorealizacji poza małżeństwem i rodziną; doświadczają poczucia wstydu lub winy za brak aspiracji do podejmowania działalności publicznej, politycznej czy intensywnej kariery zawodowej ${ }^{47}$. Feminizm wraz ze swoimi teoriami o wolności, niezależności, równości, partnerstwie, samorealizacji itp. - wyprowadził kobiety na bruk życia małżeńskiego i rodzinnego, jednocześnie w trudnych sytuacjach życiowych pozostawił samym sobie.

Wśród przyczyn migracji kobiet obok tych zarobkowych związanych z trudną sytuacji materialną, Zofia Kawczyńska-Butrym wymienia wyjazdy „dla siebie”. Należą do nich: ucieczka z peryferii do dużego świata; wyjazdy edukacyjne i zawodowe dla kobiet robiących karierę zawodową; wyjazdy matrymonialne oraz łączenie rodzin w przypadku, gdy mężowie czy partnerzy już przebywają na obczyźnie ${ }^{48}$. Szczególną kategorię stanowią wyjazdy matrymonialne. Część migrujących kobiet planuje związek małżeński z mężczyzną kraju przyjmującego. Bardzo często owe związki małżeńskie zawierane są w celach zdobycia „legalnych papierów”. Wyjazdy kobiet często łączą dwie funkcje - „za chlebem, ale i po męża”. Statystyki ukazują, że częściej kobiety aniżeli mężczyźni zawierają małżeństwa w kraju przyjmującym ${ }^{49}$.

Jeszcze inną formą migracji kobiet (zwłaszcza młodych) są takie, w których obie strony czerpią obopólne korzyści. Zwraca na nie uwagę Antoni Rajkiewicz ${ }^{50}$. Wskazuje tutaj migracje czasowe jako au-pair, co wiąże się z terminem al pari, oznaczającym porozumienie dwustronne, a w praktyce dotyczy usług domowych młodych cudzoziemek (z reguły w wieku do 30 lat), przede wszystkim studentek, w zamian za mieszkanie, utrzymanie i skromne wynagrodzenie. Ten rodzaj wyjaz-

47 M. BIEDRoń, Czemu ,winien” jest feminizm? Dylematy zwiąane z redefinicją ról rodzinnych i społecznych kobiety, w: Miłość, wierność i uczciwość na rozstajach wspótczesności. Ksztatty rodziny wspótczesnej, red. W. Muszyński, E. Sikora, Toruń 2008, s. 92-100.

48 Z. KAwCZYŃSKa-Butrym, Migracje, s. 41-42.

49 Tamże, s. 41.

50 A. Rajkiewicz, Polityka społeczna wobec procesów migracyjnych, w: Polityka społeczna. Podręcznik akademicki, red. G. Firlit-Fesnak, M. Szylko-Skoczny, Warszawa 2018, s. 310. 
dów upowszechnia się coraz bardziej, przynosząc obustronne korzyści. Najwięcej takich miejsc pracy oferują rodzinne gospodarstwa domowe w Wielkiej Brytanii, we Francji oraz krajach Beneluksu.

Nie ulega wątpliwości, iż czynnikiem wzmagającym migrację kobiet jest popyt na ich pracę. W przeciwnym wypadku motywacja migracji zarobkowej nie miałaby miejsca. Kobiety chociaż podejmują się różnych prac, np. w ogrodnictwie, gastronomii, przy sprzątaniu czy przemyśle tekstylnym, to jednak największe dla nich możliwości otworzył rynek szeroko rozumianych usług opiekuńczych. Praca taka podyktowana jest starzejącym się społeczeństwem. Wzrastająca liczba seniorów rodzi zapotrzebowanie na rzesze kobiet do ich obsługi.

Jak podaje Teresa Święćkowska, już w latach 90. Polki, podobnie jak kobiety z innych krajów Europy Wschodniej, znacznie zasiliły rynek prac domowych i opiekuńczych w Europie Zachodniej, dołączyły tym samym do grona globalnej armii pomocy domowej i opiekuńczej. Z uwagi na takie czynniki, jak legalny status, mniejszy dystans do kraju pochodzenia oraz kolor skóry, miały one lepszą pozycję niż imigrantki z Afryki czy Azji. Ciemną stroną podejmowanych prac było pochodzenie kobiet najczęściej z małych miejscowości, brak doświadczenia na emigracji i brak znajomości języka, co negatywnie wzmocniło ich podatność na wyzysk i liczne zranienia ${ }^{51}$. Zauważa się pewien mechanizm polegający na tym, że metropolia przyciąga migrujących pracowników z peryferii, oferując im pracę w usługach. Pomimo iż kobiety reprezentują wysoki poziom kompetencji i wykształcenia, to jednak należą do grona pracowników niskopłatnych. Jedną $\mathrm{z}$ przyczyn jest ta, że praca realizowana $\mathrm{w}$ domu, będąca wynikiem tradycyjnego podziału płci, nadal nie jest doceniana. Ponadto dom nie jest postrzegany jako miejsce pracy, co innego praca w sferze publicznej ${ }^{52}$.

Zadania zwłaszcza opiekuńcze nie tylko wymagają siły i cierpliwości, ale też narażają kobiety na liczne nadużycie. Zofia Kawczyńska-Butrym wymienia: przemoc - przejawiającą się w postaci molestowania seksualnego; ograniczenia (swobody poruszania się, wychodzenia z domu, korzystania z pożywienia i środków higieny, np. kąpiel raz w tygodniu); depersonalizację - przedmiotowe traktowanie osoby ,jakby jej nie było”; oraz obrażanie kobiet np. przez dzieci osoby, która ją zatrudnia ${ }^{53}$. Ponadto kobiety, zwłaszcza te znajdujące się w trudnym położeniu finansowym i silnie zmotywowane, by zarabiać pieniądze, padają ofiarami nie-

51 T. ŚwIĘćKOwSKA, Migracje i gender z perspektywy pracy domowej i opiekuńczej, http://www. isp.org.pl [dostęp: 12.07.2018].

52 E. KRUK, Wspótczesne migracje Polek do Królestwa Niderlandów, „Neerlandica Wratislaviensia" 25(2015), s. 107-108.

53 Z. KAWCZYŃSKa-Butrym, Migracje, s. 41-42. 
uczciwych praktyk ze strony pracodawców oraz biur pośrednictwa pracy, ulegają zastraszeniom i groźbom utraty źródła zarobku ${ }^{54}$.

Migracja kobiet jest opłacalna zarówno dla niej samej, jak i dla kraju przyjmującego. Wiele krajów potrzebuje migrantów nie tylko w usługach opiekuńczych, ale też np. firmach sprzątających czy gastronomii (popularny „,zmywak”). Z uwagi na te potrzeby i deficyty rąk do pracy rodaków, państwa przyjmujące tolerują nawet nielegalnych migrantów, niejako „przymykając oko” na rozwijający się proceder. Potwierdza to jedna z relacji: „Belgowie potrzebują nielegalnie przebywających w ich kraju imigrantów polskich, gdyż ich potrzebują. Polacy bowiem za niewielkie pieniądze podejmują się prac, których nikt w Belgii nie chce wykonywać" 55 .

Kobiety podejmując decyzję o migracji mają zapewne swoje powody, ale też jak pokazują badacze problematyki - również i problemy. Poprawa sytuacji kobiet zapewne wymaga zwiększonej czujności polityki rządu danego kraju i gwarancji bezpieczeństwa. Jednak wiele problemów pozostaje nadal tematem tabu, ukrywanym przed „światem”, a nawet przed własną rodziną. Wszystko to dokonuje się w obawie przed koniecznością powrotu, zniesławieniem, wstydem, a może nawet upokorzeniem. Dlatego możliwą pomocą wydaje się zapobieganie, a dosadniej ujmując - stworzenie takich warunków życia i pracy w kraju ojczystym, aby kobiety nie musiały emigrować.

\section{SKUTKI FEMINIZACJI MIGRACJI}

Feminizacja migracji powoduje wiele negatywnych skutków, które możemy rozpatrywać w wymiarze mikro- (dla rodziny) i makrostrukturalnym (dla państwa). Szczególnie dotkliwe są one dla rodziny kobiety, zwłaszcza w sytuacji pozostawiania małoletnich dzieci. Kobieta wyjeżdżająca za granicę pozostawia nie tylko dzieci (chyba że nie ma albo są już dorosłe), ale zdarza się, że i męża i starszych rodziców. Ponieważ to kobiety w większości społeczeństw pełnią funkcję opiekuńczą w rodzinie, wyjazdy kobiet powodują deficyt opieki w rodzinie. W sytuacji, gdy kobieta wyjeżdża za granicę i tam zatrudnia się w sferze usług opiekuńczych, następuje pewien paradoks, polegający na tym, że sama sprawując różne formy opieki, najbliższych członków rodziny pozostawia bez opieki.

54 E. KRUK, Wspótczesne migracje Polek, s. 116.

55 E. Kuźma, Kobiety - nielegalne imigrantki z Polski w Brukseli pod koniec XX w. Zjawisko $i$ problemy, w: Kobiety $i$ młodzież $w$ migracjach. Migracje i społeczeństwo, red. J.E. Zamojski, Warszawa 2005, s. 273. 
Deficyt opieki w rodzinach to jeden z najbardziej dotkliwych i ukrytych skutków feminizacji migracji. W literaturze migracyjnej ów deficyt określany jest jako „drenaż opieki” lub „drenaż matek”, lub też „transfer opieki między krajami biednymi a bogatymi”. Pozostawione przez kobiety ich własne dzieci we własnym kraju bez opieki stają się sierotami społecznymi, a ściślej ujmując: „eurosierotami”. Brak opieki nad dziećmi staje się jedną z ważnych kwestii społecznych w krajach pochodzenia migrantów. Dzieci i niekiedy matki kobiet migrujących pozbawione są opieki, troskliwości i miłości, podczas gdy w tym samym czasie kobiety w kraju przyjmującym sprawują opiekę nad dziećmi, osobami chorymi, starszymi przebywającymi w instytucjach opiekuńczych ${ }^{56}$.

Tego rodzaju sytuacje, w których ktoś (najczęściej kobieta) pomaga innym, ale sam zaniedbuje najbliższych członków rodziny, bardzo trafnie określił Luciano Sandrin: „samarytanami poza własnym domem”. Według tego autora „zdarzają się dzieci, które nie są w stanie troszczyć się o swoich własnych rodziców, natomiast poświęcają wiele czasu na odwiedziny i zajmowanie się innymi potrzebującymi osobami"57. Sytuacja kobiet świadczących usługi opiekuńcze obcym, na emigracji nieco różni się od tej, w której we własnym kraju, społeczności lokalnej i we własnym domu ktoś nie podejmuje działań opiekuńczych wobec najbliższych członków. Tym, co łączy te dwie sytuacje, jest fakt, iż ludzie zajmujący się innymi ludźmi (najczęściej obcymi) pozostawiają bez opieki najbliższych członków rodziny.

Skala eurosieroctwa zatacza coraz szersze kręgi i ma pewne konsekwencje. Problem eurosieroctwa bardziej istnieje w ocenie społecznej np. nauczycieli aniżeli kobiet migrujących. Według ekspertów Ministerstwa Edukacji Narodowej, dzieci dotknięte sieroctwem migracyjnym zagrożone są m.in. obniżonym poczuciem bezpieczeństwa, osamotnieniem i poczuciem odtrącenia. Występują także trudności w kształtowaniu systemu wartości. Badania psychologów potwierdzają negatywny wpływ migracji matki na rozwój dziecka. Kobiety migrujące dostrzegają rozluźnienie więzi rodzinnych, jednak pewną rekompensatę upatrują w możliwościach zaspokajania potrzeb materialnych własnych dzieci ${ }^{58}$. Migranci pozostawiający swoje dzieci, na pytanie: Czego im brakuje? - najczęściej odpowiadają, że tęsknią za dziećmi.

Według ekspertów migracji, rodzice okresowo obecni w życiu dziecka, to rodzice trudni. Są raczej gośćmi niż domownikami, a gdy przyjeżdżają, burzą ustalony porządek i odjeżdżają. Wyróżnia się trzy typy wadliwych oddziaływań

\footnotetext{
56 Z. KaWCZYŃSKa-Butrym, Migracje, s. 58-67.

${ }^{57}$ L. SANDRIN, Jak się nie wypalić pomagajac innym. Sposoby przezwyciężania zespołu wypalenia zawodowego, Kielce 2006, s. 13.

58 Zob. T. ZBYRAD, Eurosieroctwo - problemy macierzyństwa na odległość, „Problemy Opiekuńczo-Wychowawcze" 2012, nr 10, s. 5-7.
} 
rodziców migracyjnych wobec dzieci: 1) oddziaływanie bezkrytyczne zabiegające o dobro dziecka; 2) nieliczenie się z obecnością i dobrem dziecka; 3) oddziaływanie zbyt surowe (wymagające). Błędy najczęściej popełniane przez matki, to brak panowania nad sobą, brak poczucia humoru, brak konsekwencji w postępowaniu wychowawczym ${ }^{59}$. Pomimo że coraz częściej wprowadza się termin ,transnarodowe macierzyństwo" bądź „matkowanie transnarodowe" ${ }^{60}$, to jednak powstaje pytanie, w jakim stopniu odległość pozwala kobiecie realizować rolę matki i wynikające z niej obowiązki? Czy taki model matki odpowiada dziecku?

Deficyt opieki w rodzinach migrujących kobiet rozciąga się także na innych członków rodziny, zwłaszcza rodziców. Z badań przeprowadzonych w Norwegii przez Elżbietę Czapkę w 2005 roku na próbie 177 emigrantek z Polski wynika, że ponad połowa $(57,6 \%)$ ma starszych krewnych w Polsce z problemami zdrowotnymi. Niespełna połowa $(44,6 \%)$ kobiet przyznaje, że ich krewni cierpią na przewlekłe choroby. Ponadto, zgodnie z deklaracjami co dziesiąta kobieta $(10,7 \%)$ posiada $\mathrm{w}$ rodzinie starsze osoby $\mathrm{z}$ niepełnosprawnością. $\mathrm{Z}$ uwagi na to, że niepełnosprawność najczęściej generuje inne problemy związane $\mathrm{z}$ wykonywaniem codziennych obowiązków, kobiety przyznają, że ich niepełnosprawni członkowie rodzin mają problemy $z$ transportem $(27,4 \%)$, z utrzymaniem porządku $(21,8 \%)$, z robieniem zakupów $(20 \%)$ oraz z przygotowaniem posiłku $(9,2 \%)$. Kobiety zdają sobie sprawę z trudnej sytuacji swoich rodziców, opisują ich zmagania się $\mathrm{z}$ codziennym funkcjonowaniem i poczuwają się do odpowiedzialności za sprawowanie funkcji opiekuńczej. Niektóre nawet odczuwają powinności opieki względem dziadków. Zdarzyły się sporadyczne przypadki (dokładnie 3 uczestniczki badań), w których kobiety nie odczuwały zobowiązań opiekuńczych. Powodem były najczęściej trudne doświadczenia z dzieciństwa (np. matka alkoholiczka) czy trudna relacja $\mathrm{z}$ rodzicem ${ }^{61}$. Na ogół badane kobiety zdawały sobie sprawę z ograniczeń w sprawowaniu funkcji opiekuńczej, zaś deklarowanym typem opieki - jest „typ opieki na odległość oraz delegacja zadań opiekuńczych”. Koordynowanie zadań opiekuńczych czy opieka świadczona osobiście - rzadko przejawiały się w deklaracjach kobiet. Fizyczna nieobecność kobiety uniemożliwia podejmowanie usług opiekuńczych. Jak przyznała jedna z kobiet: „Zastanawiam się, ale to się

59 A. PAwlak, Transnarodowe macierzyństwo a transnarodowe ojcostwo - podobieństwa i różnice $w$ realizacji i spotecznym odbiorze praktyk rodzicielskich migrujacych matek i migrujacych ojców, w: Opieka nad dziećmi i starszymi rodzicami w rodzinach migrujących matek, red. Z. Kawczyńska-Butrym, E. Czapka, Lublin 2016, s. 98-99.

${ }^{60}$ Zob. T. Szlendak, Socjologia rodziny. Ewolucja, historia, zróżnicowanie, Warszawa 2010, s. 494.

${ }^{61}$ E. CzAPKA, Zakresy opieki i strategie opiekuńcze polskich migrantek $w$ Norwegii realizowane wobec starszych członków rodziny w Polsce, w: Opieka nad dziećmi i starszymi rodzicami, s. 165-169. 
na zastanawianiu kończy, bo mój wpływ na sytuację jest raczej niewielki [...]. Ja nie jestem w stanie na odległość tego w żaden sposób zaspokoić. Jak jestem na miejscu, to staram się jej dużo rzeczy załatwić, które można w tym czasie zrobić. Podwieźć tam, gdzie ona akurat potrzebuje. Tak na co dzień to nie jest możliwe"62.

Jedną ze strategii podejmowaną przez kobiety na emigracji w zakresie opieki zarówno nad dziećmi, jak i starszymi rodzicami jest delegowanie zadań opiekuńczych na innych członków rodziny pozostających w kraju, najczęściej siostry bądź innych krewnych. Badania wśród polskich emigrantek we Włoszech pokazują, że kobiety dobrze radzą sobie $\mathrm{w}$ organizowaniu migracji poprzez tworzenie nieformalnych sieci wsparcia krewnych i przyjaciół, które umożliwiają im równocześnie wypełnienie dwóch zadań: pracy zarobkowej za granicą oraz wypełnianie obowiązków rodzicielskich i domowych ${ }^{63}$. Nie ulega wątpliwości, iż kobiety migrujące potrafią bardzo dobrze zorganizować opiekę nad swoimi bliskimi i nie pozostawiają ich na przysłowiową ,pastwę losu”. Jednak problem sprowadza się do ich fizycznej nieobecności w życiu dziecka czy starzejących się rodziców, którzy potrzebują zarówno matki, jak i córki w codziennym funkcjonowaniu.

W perspektywie migracji kobiet funkcja opiekuńcza rodziny zyskuje nową jakość. Migracja kobiet zaburza funkcje opiekuńcze rodziny, kobiety, które są matkami, córkami, żonami, pozostawiają zawsze kogoś z bliskich, kto tej opieki potrzebuje. O ile dawniej obowiązki opiekuńcze w sposób naturalny przejmowały kobiety jako matki, żony i córki, o tyle obecnie mamy do czynienia z transferem opieki na innych krewnych bądź nawet obcych. Migracja kobiet powoduje ogromne deficyty w zakresie opieki we własnych rodzinach. Jak na ironię, te same kobiety, które muszą zorganizować pomoc dla swoich bliskich, świadczą usługi opiekuńcze obcym. Opieka zyskała nowy wymiar ekonomiczny. Można zaryzykować tezę, że opieka nad własnymi krewnymi nie jest opłacalna ekonomicznie. Niegdyś bezpłatna opieka została przeliczona na pieniądze, które można zyskać sprawując opiekę nad obcymi. Migracje kobiet potwierdzają pewną kalkulatywność opieki. Jednak ma ona jedynie wymiar materialny. Natomiast w sferze moralnej rodzą się dylematy: Czy warto poświęcać swoich najbliższych (szczególnie dzieci) dla zagranicznych srebrników? Czy te straty można będzie odrobić? Czy zyski materialne nie okażą się mizerne wobec strat relacji rodzicielskich i niedopełnionych obowiązków wobec rodziców?

62 Tamże, s. 169.

${ }^{63}$ A. PawlaK, Matka - Emigrantka kontra Matka - Polka. Normatywne i nienormatywne modele macierzyństwa $w$ społeczeństwie ryzyka, w: Rodzina - terra incognito? Przemiany rodziny $w$ XXI wieku, red. A. Pawlak, E. Hyży, Łódź 2012, s. 231. 


\section{ZAKOŃCZENIE}

Zjawisko migracji kobiet wpisuje się w rozsławione przez Urlicha Becka „społeczeństwo ryzyka" ${ }^{64}$. Kobiety migrujące zarobkowo wiele ryzykują pozostawiając najbliższych członków swojej rodziny. Ryzykowne stają się racje rodzinne, które w wyniku fizycznej nieobecności mogą ulec rozluźnieniu, oziębłości, niezrozumieniu, obojętności czy nawet zrodzić dystanse. Wyjazdy zagraniczne zawsze były ryzykowne. Jednak kiedy kobieta-matka migruje zostawiając dzieci, męża, rodziców - ryzyko potęguje się dla tych, którzy zostają i dla niej samej. Nikt nie jest w stanie zagwarantować bezpieczeństwa ani samej kobiecie, ani jej najbliższym. Wywołany falą migracji drenaż matek i drenaż opieki, w istotny sposób utrudnia funkcjonowanie rodziny.

Na migrację kobiet można spojrzeć w szerszym kontekście procesów społecznych - makrostrukturalnych. Jednym z nich jest globalizacja. Jak zauważa Teresa Świećkowska, zjawisko rosnącej migracji kobiet w ostatnich dekadach wpisuje się w kontekst globalnych zmian gospodarczych i politycznych wskutek globalizacji. Praca domowa i opiekuńcza stała się tanim produktem, który można kupić, globalny rynek migrującej siły roboczej oferuje duże zasoby tych usług. Globalny rynek prac domowych i opiekuńczych powstaje na skrzyżowaniu wielu hierarchicznych porządków, w tym systemu społecznych podziałów pracy reprodukcyjnej oraz reżimów migracyjnych. Wszystkie porządki są zakorzenione w globalnych i lokalnych nierównościach ekonomicznych. Poprawa sytuacji w zakresie równości płci jest ściśle związana $\mathrm{z}$ koniecznością systemowych zmian nie tylko $\mathrm{w}$ świadomości kobiet i mężczyzn, czy w kulturze, ale przede wszystkim w reżimach ekonomicznych i migracyjnych ${ }^{65}$.

Globalizacja otworzyła wiele możliwości rozwoju niespotykanych dotąd. Ale należy pamiętać, że zrodziła także problemy związane chociażby z nieograniczonymi możliwościami przemieszczania się i dostępności do pracy. Globalny rynek prac domowych kusi i przyciąga, ale tym samym wyrywa z własnych gniazd narodowych, lokalnych i rodzinnych. Zauważyć można pewien paradoks oparty na dychotomii świadczenia usług opiekuńczych i ich deficytu. W centrum, a zarazem łącznikiem staje się kobieta, która pozostawia swoich najbliższych, aby pomagać innym. $Z$ dużym prawdopodobieństwem sytuacje te nie miałyby miejsca, gdyby nie rozciągające się w globalnym świecie nierówności społeczne. Mechanizmy świadczonych usług są jednostronne i niemal odwieczne, tzn. biedni tego świata są w kieszeniach bogatych. Feminizacja migracji w znacznym stopniu obejmuje

${ }^{64}$ Zob. U. Beck, Społeczeństwo ryzyka. W drodze do innej nowoczesności, Warszawa 2004.

65 T. ŚwIĘć́KоwsKa, Migracje i gender, s. 5-21. 
kraje biedne, w których generowane są na tym tle kolejne problemy. Największymi „wygranymi” są bogate społeczeństwa, które stać na „zakup” niemal każdej siły roboczej.

W wielu zawodach nakłady pracy żywej są zastępowane przez maszyny - roboty. Zadania opiekuńcze są specyficznym rodzajem pracy niezastępowanej przez nawet najbardziej wyspecjalizowane technologie. Żaden robot nie jest w stanie zmienić pampersów, pościelić łóżka, podać leków. Maszyna bez sterowania nie pościera kurzu na półce, nie przygotuje posiłku, nie zrobi zakupów. Ale nade wszystko nikt i nic nie jest w stanie zastąpić dzieciom matki ani zapewnić ciepła rodzinnego, wesprzeć w trudnych chwilach, pocieszyć, przytulić, obdarzyć miłością. To z tych ostatnich względów migracja kobiet jest tak dotkliwa szczególnie dla rodziny. Skutki feminizacji migracji ponoszą także społeczności lokalne i całe społeczeństwa, które muszą się uporać zarówno z problemem eurosieroctwa, jak i deficytami w zakresie szeroko pojętych usług opiekuńczych. To tylko niektóre z problemów generowane przez feminizację migracji. Do nich należałoby dołączyć całą listę innych, które wymagają odrębnej analizy.

\section{BIBLIOGRAFIA}

ADAmski F., Rodzina. Wymiar społeczno-kulturowy, Kraków: Wydawnictwo UJ 2002.

BECK U., Społeczeństwo ryzyka. W drodze do innej nowoczesności, Warszawa: Scholar 2004.

Biedroń M., Czemu „winien” jest feminizm? Dylematy związane z redefinicją ról rodzinnych i społecznych kobiety, w: Miłość, wierność i uczciwość na rozstajach współczesności. Kształty rodziny współczesnej, red. W. Muszyński, E. Sikora, Toruń: Adam Marszałek 2008.

Chyra-Rolicz Z., Związek Polek w Ameryce, w: Kobiety i procesy migracyjne, red. A. Chlebowska, K. Sierakowska, Warszawa: Neriton 2010.

CZAPKA E., Zakresy opieki i strategie opiekuńcze polskich migrantek w Norwegii realizowane wobec starszych członków rodziny w Polsce, w: Opieka nad dziećmi i starszymi rodzicami w rodzinach migrujących matek, red. Z. Kawczyńska-Butrym, E. Czapka, Lublin: Polihymnia 2016.

DAJNowicz M., Migracje małżeńskie kobiet polskich na pograniczu północno-wschodnim w początkach XX wieku, w: Kobiety i procesy migracyjne, red. A. Chlebowska, K. Sierakowska, Warszawa: Neriton 2010.

Galaj-Dempniak R., Migracje kobiet zamężnych w świetle pamiętników staropolskich pisanych przez szlachtę, w: Kobiety i procesy migracyjne, red. A. Chlebowska, K. Sierakowska Warszawa: Neriton 2010. 
GARAPICH M.P., Życie na huśtawce. Londyńczycy. Nowy rodzaj migracji po wejściu Polski do Unii Europejskiej, w: Za chlebem i wolnością. 200 lat nieprzerwanej migracji z ziem polskich, „Pomocnik Historyczny Polityki” 2018, nr 4, s. 124-129.

GidDENS A., Socjologia, Warszawa: PWN 2004.

KARPIŃSKA M., Kobiety wielkiej emigracji - próba portretu socjologicznego, w: Kobiety i procesy migracyjne, red. A. Chlebowska, K. Sierakowska, Warszawa: Neriton 2010. KAWCZYŃSKA-Butrym Z., Migracje. Wybrane zagadnienia, Lublin: UMCS 2009.

KŁONCZYŃSKi A., Polki w Szwecji w latach 1945-1980. Emigracja polityczna, ekonomiczna i matrymonialna, w: Kobiety i procesy migracyjne, red. A. Chlebowska, K. Sierakowska, Warszawa: Neriton 2010.

Konic H., Prawo małżeńskie obowiązujące w b. Królestwie Kongresowym, Warszawa 1924.

KozIELSKA, Poakcesyjne migracje zarobkowe. Kontekst teoretyczno-empiryczny. Wsparcie społeczne, Poznań: Wydawnictwo Naukowe Uniwersytetu Adama Mickiewicza 2014.

Kożuchowski A., Wielka Emigracja, w: Za chlebem i wolnością. 200 lat nieprzerwanej migracji z ziem polskich, „Pomocnik Historyczny Polityki” 2018, nr 4, s. 16-23.

Krajewski A., Polaca czyli prostytutka. Domy publiczne w Ameryce Południowej przed stu laty pękały w szwach od kobiet uprowadzonych z ziem polskich, w: Za chlebem i wolnością. 200 lat nieprzerwanej migracji z ziem polskich, „Pomocnik Historyczny Polityki" 2018, nr 4, s. 40-41.

KRUK E., Współczesne migracje Polek do Królestwa Niderlandów, „Neerlandica Wratislaviensia" 25(2015), s. 103-121.

KUBIS B., Wpływ przymusowych migracji na powojenne losy kobiet polskich - w świetle wspomnień, w: Kobiety i procesy migracyjne, red. A. Chlebowska, K. Sierakowska, Warszawa: Neriton 2010.

KuŹma E., Kobiety - nielegalne imigrantki z Polski w Brukseli pod koniec XX w. Zjawisko i problemy, w: Kobiety i młodzież w migracjach. Migracje i społeczeństwo, red. J.E. Zamojski, Warszawa: Neriton 2005.

MATEJKo I., Herby rodowe jako przejaw migracji małżeńskich na pieczęciach księżnych legnicko-brzeskich, w: Kobiety i procesy migracyjne, red. A. Chlebowska, K. Sierakowska, Warszawa: Neriton 2010.

MęDrZECKI W., My naród emigrantów, w: Za chlebem i wolnością. 200 lat nieprzerwanej migracji z ziem polskich, „Pomocnik Historyczny Polityki” 2018, nr 4, s. 7-10.

OetTingEn U., Migracje ziemianek w latach I wojny światowej - uwarunkowania i wpływ na styl życia, w: Kobiety i procesy migracyjne, red. A. Chlebowska, K. Sierakowska, Warszawa: Neriton 2010.

PAWlaK A., Matka - Emigrantka kontra Matka - Polka. Normatywne i nienormatywne modele macierzyństwa w społeczeństwie ryzyka, w: Rodzina - terra incognito? Przemiany rodziny w XXI wieku, red. A. Pawlak, E. Hyży, Łódź: Uniwersytet Medyczny w Łodzi 2012.

PAWlaK A., Transnarodowe macierzyństwo a transnarodowe ojcostwo - podobieństwa i różnice w realizacji i społecznym odbiorze praktyk rodzicielskich migrujących matek i migrujących ojców, w: Opieka nad dziećmi i starszymi rodzicami w rodzinach 
migrujących matek, red. Z. Kawczyńska-Butrym, E. Czapka, Lublin: Polihymnia 2016, s. 91-109.

PobóG-Lenartowicz A., Viola, Bułgarka, Księżną Opolską. Przyczynek do migracji małżeńskich w średniowieczu, w: Kobiety i procesy migracyjne, red. A. Chlebowska, K. Sierakowska, Warszawa: Neriton 2010.

RAJKIEWICZ A., Polityka społeczna wobec procesów migracyjnych, w: Polityka społeczna. Podręcznik akademicki, red. G. Firlit-Fesnak, M. Szylko-Skoczny, Warszawa: PWN 2018. Rocznik Statystyczny GUS, Warszawa 2016.

SANDRIN L., Jak się nie wypalić pomagając innym. Sposoby przezwyciężania zespołu wypalenia zawodowego, Kielce: Jedność 2006.

Szast M., Migracje wczoraj i dziś. Problematyka migracji przedakcesyjnych i poakcesyjnych z Polski, „Studia Polonijne” 37(2016), s. 5-24.

SzAST M., W Irlandii wygodniej, ale w Polsce lepiej. Kapitał społeczno-kulturowy i ocena sytuacji życiowej polskich migrantów w Irlandii, Lublin: Ośrodek Badań nad Polonią i Duszpasterstwem Polonijnym KUL 2017.

SzLENDAK T., Socjologia rodziny. Ewolucja, historia, zróżnicowanie, Warszawa: PWN 2010.

WŁoDeK R., Z kamerą na Greenpoincie. Nostalgicznie, komediowo, bezlitośnie - jak emigrantów pokazano w filmach, w: Za chlebem i wolnością. 200 lat nieprzerwanej migracji z ziem polskich, „Pomocnik Historyczny Polityki” 2018, nr 4, s. 114-118.

ZAWADZKI T., Na fali. Masowe wyjazdy zarobkowe wpłynęły na rozwój polskiej żeglugi, w: Za chlebem i wolnością. 200 lat nieprzerwanej migracji z ziem polskich, „Pomocnik Historyczny Polityki" 2018, nr 4, s. 52-53.

ZBYRAD T., Eurosieroctwo - problemy macierzyństwa na odległość, „Problemy Opiekuńczo-Wychowawcze" 2012, nr 10, s. 3-9.

\section{WSPÓŁCZESNE OBLICZA FEMINIZACJI MIGRACJI I JEJ SKUTKI}

\section{Streszczenie}

Polacy należą do narodów bardzo mocno osadzonych w procesach migracyjnych. Migracje z ziem polskich znane były od dawna. Jednak istnieje pewna różnica pomiędzy migracjami w przeszłości a obecnymi. Tym, co je najbardziej różnicuje, to kategorie ludzi migrujących ze względu na płeć. Niegdyś migrowali wyłącznie mężczyźni, zaś współcześnie dominującą grupę stanowią kobiety. Z uwagi na ich niespotykaną dotąd liczbę wprowadzono termin „feminizacja migracji”. To ona symbolizuje migracje końca XX i początku XXI wieku. Migracja kobiet odciska swoje piętno na rodzinie i społeczeństwie. Jednym z najbardziej dotkliwych skutków jest deficyt usług opiekuńczych w kraju migrujących kobiet. Deficyt obejmuje zarówno dzieci, jak i starszych członków rodziny, zwłaszcza rodziców. Artykuł zwraca uwagę na zjawisko feminizacji migracji, przemiany na przestrzeni lat i skutki.

Słowa kluczowe: kobieta; migracja; feminizacja migracji; opieka; eurosieroctwo 


\section{PRESENT FACES OF MIGRATION FEMINIZATION AND ITS EFFECTS}

\section{Sum mary}

People from Polish belong to nations very strongly embedded in migration processes. Migrations from Polish lands have been known for a long time. However, there is a difference between past and present migrations. What makes them the most different is the categories of people who migrate because of their gender. Once only men were migrating, while the dominant group is women. Due to their unprecedented number, the term "feminisation of migration" has been introduced. It symbolizes the migration of the late twentieth and early twenty-first century. Migration of women impresses its mark on the family and society. One of the most severe effects is the deficit of care services in the country of migrant women. The deficit covers both children and older family members, especially parents. The article draws attention to the phenomenon of feminization of migration, changes over the years and effects.

Key words: woman; migration; feminisation of migration; care; abandoned children 